\title{
A novel combination of multiple primary carcinomas: Urinary bladder transitional cell carcinoma, prostate adenocarcinoma and small cell lung carcinoma- report of a case and review of the literature
}

\author{
Anastassios V Koutsopoulos*1, Konstantina I Dambaki1 ${ }^{1}$ George Datseris', \\ Elpida Giannikaki ${ }^{1}$, Marios Froudarakis ${ }^{2}$ and Efstathios Stathopoulos ${ }^{1}$
}

Address: ${ }^{1}$ Department of Pathology, Heraklion University Hospital, Greece and ${ }^{2}$ Department of Pneumonology, Heraklion University Hospital, Greece

Email: Anastassios V Koutsopoulos* - akoutsop@med.uoc.gr; Konstantina I Dambaki - ntampak@hotmail.com;

George Datseris - gdatseris@hotmail.com; Elpida Giannikaki - lindagianikak@hotmail.com; Marios Froudarakis - mfroud@med.uoc.gr;

Efstathios Stathopoulos - stath@med.uoc.gr

* Corresponding author

Published: 26 July 2005

World Journal of Surgical Oncology 2005, 3:5 I doi:10.1 186/1477-7819-3-

51

This article is available from: http://www.wjso.com/content/3/I/5।

(c) 2005 Koutsopoulos et al; licensee BioMed Central Ltd.

This is an Open Access article distributed under the terms of the Creative Commons Attribution License (http://creativecommons.org/licenses/by/2.0), which permits unrestricted use, distribution, and reproduction in any medium, provided the original work is properly cited.
Received: 19 March 2005

Accepted: 26 July 2005

\begin{abstract}
Background: The incidence of multiple primary malignant neoplasms increases with age and they are encountered more frequently nowadays than before, the phenomenon is still considered to be rare.

Case presentation: We report a case of a man in whom urinary bladder transitional cell carcinoma, metachronous prostate adenocarcinoma and small cell lung carcinoma were diagnosed within an eighteen-month period. The only known predisposing factor was that he was heavy smoker (90-100 packets per year). The literature on the phenomenon of multiple primary malignancies in a single patient is reviewed and the data is summarized.

Conclusion: It is important for the clinicians to keep in mind the possibility of a metachronous (successive) or a synchronous (simultaneous) malignancy in a cancer patient. It is worthy mentioning this case because clustering of three primary malignancies (synchronous and metachronous) is of rare occurrence in a single patient, and, to our knowledge, this is the first report this combination of three carcinomas appearing in the same patient.
\end{abstract}

\section{Background}

The phenomenon of multiple primary malignant neoplasms in the same individual was described firstly by Billroth at the end of the $19^{\text {th }}$ century [1]. Since then, several cases of double or even triple primary malignant neoplasms have been reported. It is believed that multiple primary malignant neoplasms now occur more frequently than before. Although, not uncommon, they occur more often in elderly patients, as the incidence of malignancies increases with age. The diagnosis of second primary neoplasms is rising as a result of prolonged survival of patients treated for previous malignancy with alkylating agents, topoisomerase II inhibitors, and/or radiotherapy[2]. A review of the recent literature indicates clearly 


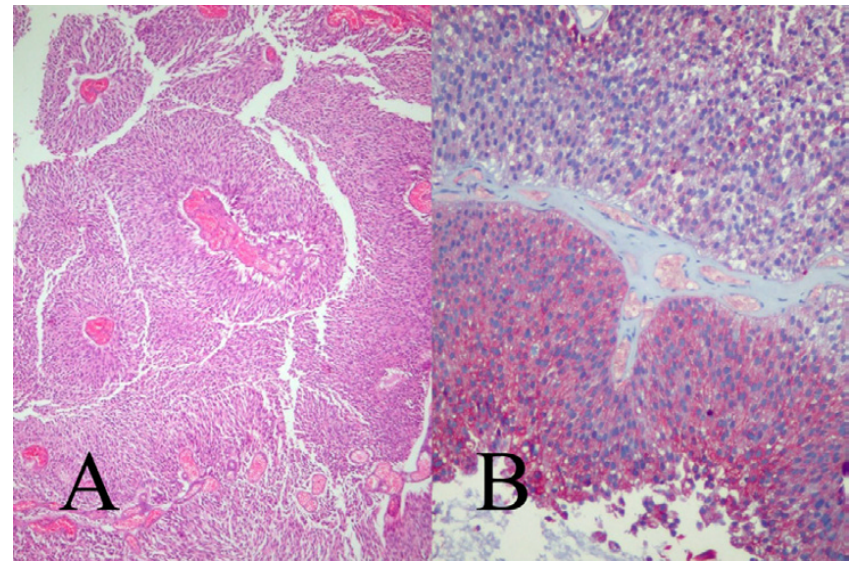

Figure I

Microscopically, the extracted urinary bladder tissue particles proved to be pieces of papillary transitional cell carcinoma grade II [A) hematoxylin and eosin $\times 40]$ and immunohistochemically they expressed cytokeratin 7 [B] cytokeratin $7 \times 100]$.

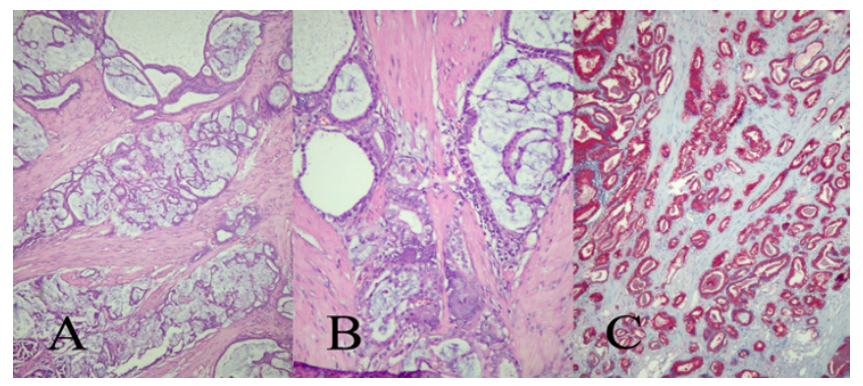

Figure 2

Histologically, in most of the prostate tissue fragments were recognized areas of, partially mucinous, adenocarcinoma of the prostate, grade II-III (A. hematoxylin and eosin $\times 40$, B: hematoxylin and eosin $\times 100)$. The tumor cells were strongly positive for PSA (C: PSA $\times$ 40).

that they appear more frequently in the upper digestive tract, respiratory system, head and neck region, or urogenital system; the reported incidence ranges from $2 \%$ to $10 \%[3]$.

In this report we present a patient who developed primary bladder carcinoma and metachronous prostate and small cell lung carcinoma (SCLC) within an eighteen-month period. This combination of multiple primary carcinomas, to our knowledge, has never been reported in the literature.

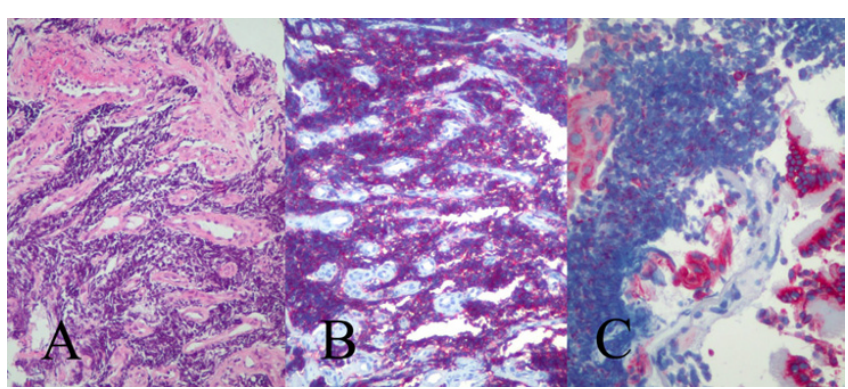

\section{Figure 3}

The bronchial mucosa showed extensive invasion from small blue round cells (A: hematoxylin and eosin $\times 100)$ that were positive for the neuroendocrine marker CD56 (B: $\times 200)$ and pan-cytokeratin (C: $\times 200)$.

\section{Case presentation}

A 75-year old ex-smoker (90-100 packet per year) underwent a transurethral resection of urinary bladder papilloma in February 2002. The histology of resected specimen was papillary transitional cell carcinoma grade II (Figure 1A). The tumor cells were positive for cytokeratin 7 (Figure 1B) and negative for cytokeratin 20. There were no muscle fibers in the examined tissue. The ultrasound examination of the urogenital system revealed nodular hyperplasia of the prostate. The tumor clinical stage according to the American Cancer Committee U.I.C.C. (1992) was Ta. Patient's cancer relapsed at the end of the same year and he underwent a programmed transurethral resection of the tumor, which proved to be papillary transitional cell carcinoma grade I-II. No lamina propria or muscle invasion was detected. The patient was also treated with intracystic infusion of bacille Calmette-Guerin (BCG). Ten days later, because of urine retention, he underwent transurethral resection of the prostate. Multiple tissue fragments of total dimensions $4.5 \times 3.5 \times 2.2 \mathrm{~cm}$ were examined histologically. Seven out of the 10 examined slides revealed foci of partially mucinous (Figure 2A) adenocarcinoma of the prostate (the greatest measured focus was $8.5 \mathrm{~mm}$ in maximum diameter), Gleason grade II-III and Gleason score 5 (Figure 2A, B). Immunohistochemical study was performed and showed strong positivity for Prostate Specific antigen (PSA) (Figure 2C) whereas; no expression of carcinoembryonic antigen (CEA) was detected in tumor cells. These findings confirmed the diagnosis of primary prostate adenocarcinoma. The tumor's stage according to the 1997 TNM staging system of prostatic adenocarcinoma was T1b. Serum prostate specific antigen (PSA) levels were elevated $(9 \mathrm{ng} / \mathrm{mL}$ ) before surgery. No additional surgical treatment was given and at follow-up visits prostate specific antigen (PSA) levels measurement and intracystic injection of BCG was 
Table I: There are summarized the cases of triple or more malignancies, the first author, journal, year of publication and combination of neoplasms.

\begin{tabular}{|c|c|c|c|c|c|c|c|}
\hline & Year & Author & Ist Malignancy & 2nd Malignancy & 3rd Malignancy & 4th Malignancy & 5th Malignancy \\
\hline I & 1949 & $\begin{array}{l}\text { Crail H.W } \\
{[6]}\end{array}$ & Thyroid Carcinoma & Rectal Carcinoma & Medulloblastoma & & \\
\hline 2 & 1974 & $\begin{array}{l}\text { Hamoudi } \\
\text { A.B.[7] }\end{array}$ & Colon Carcinoma & Thymus Carcinoma & Skin Carcinoma & Astrocytoma G3 & \\
\hline 3 & 1975 & $\begin{array}{l}\text { Ohsato K. } \\
{[8]}\end{array}$ & Colon Carcinoma & Astrocytoma G3 & Duodenal Carcinoma & & \\
\hline 4 & 1976 & $\begin{array}{l}\text { Kawanami } \\
\text { K. }[9]\end{array}$ & Ileum Carcinoma & Glioblastoma & Colon Carcinoma & & \\
\hline 5 & 1976 & $\begin{array}{l}\text { Rovinescu } \\
\text { I.[4] }\end{array}$ & $\begin{array}{l}\text { Clear Cell Carcinoma } \\
\text { Of Kidney }\end{array}$ & $\begin{array}{l}\text { Transitional Cell } \\
\text { Carcinoma Of Bladder }\end{array}$ & Prostate Carcinoma & & \\
\hline 6 & 1979 & Itoh H.[10] & Colon Carcinoma & Stomach Carcinoma & Astrocytoma G3 & & \\
\hline 7 & 1979 & $\begin{array}{l}\text { Mullen } \\
\text { J.L.[II] }\end{array}$ & Hodgkin' Disease & $\begin{array}{l}\text { Squamous Cell } \\
\text { Carcinoma Of Larynx }\end{array}$ & $\begin{array}{l}\text { Squamous Cell } \\
\text { Carcinoma In Esophagus }\end{array}$ & & \\
\hline 8 & 1979 & Pinel J.[12] & $\begin{array}{l}7 \text { Squamous Cell } \\
\text { Carcinomas In } 9 \text { Years }\end{array}$ & & & & \\
\hline 9 & 1980 & $\begin{array}{l}\text { Cohen } \\
\text { C. [13] }\end{array}$ & $\begin{array}{l}\text { Multiple Cutaneous } \\
\text { Squamous Cell } \\
\text { Carcinomas }\end{array}$ & $\begin{array}{l}\text { Multiple Cutaneous Basal } \\
\text { Cell Carcinomas }\end{array}$ & $\begin{array}{l}\text { Diffuse Poorly } \\
\text { Differentiated } \\
\text { Lymphocytic Lymphoma }\end{array}$ & & \\
\hline 10 & 1982 & $\begin{array}{l}\text { Friedman } \\
\text { C.D. [I4]. }\end{array}$ & Breast Carcinoma & Colon Carcinoma & Glioblastoma In Brain & & \\
\hline II & 1983 & Li F.P.[15] & Colon Carcinoma & Astrocytoma G3 & Leukemia & & \\
\hline 12 & 1984 & $\begin{array}{l}\text { Haibach } \\
\text { H.[16] }\end{array}$ & Thyroid Carcinoma & Renal Carcinoma & Duodenal Carcinoma & & \\
\hline 13 & 1985 & Alessi E.[17] & $\begin{array}{l}\text { Multiple Sebaceous } \\
\text { Tumors }\end{array}$ & Keratoacanthoma & $\begin{array}{l}3 \text { Primary } \\
\text { Adenocarcinomas Of } \\
\text { Colon }\end{array}$ & & \\
\hline 14 & 1985 & $\begin{array}{l}\text { Kobayashi } \\
\text { T. [18] }\end{array}$ & Uterus Carcinoma & Stomach Carcinoma & Breast Carcinoma & Glioblastoma In Brain & \\
\hline 15 & 1985 & $\begin{array}{l}\text { Megighian } \\
\text { D.[19] }\end{array}$ & $\begin{array}{l}\text { Squamous Cell } \\
\text { Carcinoma Of Parotid }\end{array}$ & $\begin{array}{l}\text { Squamous Cell } \\
\text { Carcinoma Of Tongue }\end{array}$ & $\begin{array}{l}\text { Squamous Cell } \\
\text { Carcinoma Of Soft Palate }\end{array}$ & $\begin{array}{l}\text { Squamous Cell } \\
\text { Carcinoma Of Larynx }\end{array}$ & $\begin{array}{l}\text { Squamous Cell } \\
\text { Carcinoma Of } \\
\text { Hypopharynx }\end{array}$ \\
\hline 16 & 1985 & $\begin{array}{l}\text { Staren } \\
\text { E.D.[20] }\end{array}$ & Carcinoma Of Larynx & $\begin{array}{l}\text { Carcinoma Of Floor Of } \\
\text { Mouth }\end{array}$ & $\begin{array}{l}\text { Dual Primary } \\
\text { Bronchogenic } \\
\text { Carcinomas }\end{array}$ & & \\
\hline 17 & 1986 & $\begin{array}{l}\text { Craig } \\
\text { D.M.[2I] }\end{array}$ & $\begin{array}{l}\text { Squamous Cell } \\
\text { Carcinoma Of The Floor } \\
\text { Of The Mouth }\end{array}$ & Adenocarcinoma Of Lung & $\begin{array}{l}\text { Squamous Cell } \\
\text { Carcinoma Of Larynx }\end{array}$ & $\begin{array}{l}\text { Squamous Cell } \\
\text { Carcinoma Of The } \\
\text { Tongue }\end{array}$ & \\
\hline 18 & 1986 & $\begin{array}{l}\text { Ogasawara } \\
\text { K.[22] }\end{array}$ & Breast Carcinoma & Breast Carcinoma & Lung Carcinoma & Glioblastoma In Brain & Thyroid Carcinoma \\
\hline 19 & 1987 & $\begin{array}{l}\text { Hayashi } \\
\text { K.[23] }\end{array}$ & Colon Carcinoma & Rectal Carcinoma & Glioblastoma In Brain & & \\
\hline 20 & 1987 & $\begin{array}{l}\text { Kobayashi } \\
\text { T.[24] }\end{array}$ & Uterus Carcinoma & Stomach Carcinoma & Glioblastoma In Brain & & \\
\hline 21 & 1988 & Ohi H. [25] & Skin Carcinoma & Medulloblastoma & Thyroid Carcinoma & & \\
\hline 22 & 1991 & $\begin{array}{l}\text { Baigrie } \\
\text { R.J.[26] }\end{array}$ & 7 Primary Carcinomas & & & & \\
\hline 23 & 1991 & $\begin{array}{l}\text { Solan } \\
\text { M.J.[27] }\end{array}$ & Two Breast Carcinomas & Thyroid Carcinoma & Multiple Skin Carcinomas & & \\
\hline 24 & 1992 & $\begin{array}{l}\text { Melkert } \\
\text { P.W. [28] }\end{array}$ & $\begin{array}{l}\text { Squamous Cell } \\
\text { Carcinoma Of Skin }\end{array}$ & $\begin{array}{l}\text { Squamous Cell } \\
\text { Carcinoma Of Vulva }\end{array}$ & $\begin{array}{l}\text { Squamous Cell } \\
\text { Carcinoma Of Vagina }\end{array}$ & $\begin{array}{l}\text { Squamous Cell } \\
\text { Carcinoma Of Anus }\end{array}$ & $\begin{array}{l}\text { Squamous Cell } \\
\text { Carcinoma Of Cervix } \\
\text { Uteri }\end{array}$ \\
\hline 25 & 1992 & $\begin{array}{l}\text { Marcos } \\
\text { Sanchez F. } \\
\text { [29] }\end{array}$ & Colon Carcinoma & Renal Carcinoma & Breast Carcinoma & & \\
\hline 26 & 1993 & $\begin{array}{l}\text { Brugieres L. } \\
{[30]}\end{array}$ & Soft Tissue Tumor & Brain Tumor & Thyroid Carcinoma & Breast Carcinoma & \\
\hline 27 & 1993 & $\begin{array}{l}\text { Kikuchi T. } \\
{[31]}\end{array}$ & Glioblastoma & Colon Carcinoma & Colon Carcinoma & & \\
\hline 28 & 1993 & $\begin{array}{l}\text { Shiseki } \\
\text { M.[32] }\end{array}$ & Skin Carcinoma & Colon Carcinoma & Glioblastoma In Brain & & \\
\hline 29 & 1994 & $\begin{array}{l}\text { Bumpers } \\
\text { H.L.[33] }\end{array}$ & $\begin{array}{l}\text { Squamous Cell } \\
\text { Carcinoma Of Larynx }\end{array}$ & $\begin{array}{l}\text { Squamous Carcinoma Of } \\
\text { Lung }\end{array}$ & $\begin{array}{l}\text { Adenocarcinoma Of } \\
\text { Breast }\end{array}$ & $\begin{array}{l}\text { Adenocarcinoma Of } \\
\text { Colon }\end{array}$ & \\
\hline 30 & 1994 & $\begin{array}{l}\text { Nishihara K. } \\
\text { [34] }\end{array}$ & $\begin{array}{l}\text { Papillary } \\
\text { Adenocarcinoma Of } \\
\text { Papilla Of Vater }\end{array}$ & $\begin{array}{l}\text { Papillary Adenocarcinoma } \\
\text { Of Common Bile Duct }\end{array}$ & $\begin{array}{l}\text { Papillary } \\
\text { Adenocarcinoma Of } \\
\text { Pancreas }\end{array}$ & & \\
\hline 31 & 1995 & $\begin{array}{l}\text { Angeli- } \\
\text { Besson C. } \\
{[35]}\end{array}$ & $\begin{array}{l}\text { Chronic Myeloid } \\
\text { Leukemia, Multiple } \\
\text { Squamous Cell } \\
\text { Carcinomas }\end{array}$ & & & & \\
\hline 32 & 1996 & $\begin{array}{l}\text { Hayashi } \\
\text { T.[36] }\end{array}$ & $\begin{array}{l}\text { Squamous Cell } \\
\text { Carcinoma In Soft Palate }\end{array}$ & $\begin{array}{l}\text { Squamous Cell } \\
\text { Carcinoma In Larynx }\end{array}$ & $\begin{array}{l}\text { Squamous Cell } \\
\text { Carcinoma In Esophagus }\end{array}$ & & \\
\hline 33 & 1996 & $\begin{array}{l}\text { Nagane } \\
\text { M.[37] }\end{array}$ & $\begin{array}{l}\text { Tubular } \\
\text { Adenocarcinoma Of } \\
\text { Stomach }\end{array}$ & $\begin{array}{l}\text { Transitional Cell } \\
\text { Carcinoma Of Bladder }\end{array}$ & Glioblastoma In Brain & & \\
\hline
\end{tabular}


Table I: There are summarized the cases of triple or more malignancies, the first author, journal, year of publication and combination of neoplasms. (Continued)

\begin{tabular}{|c|c|c|c|c|c|c|c|}
\hline 34 & 1996 & $\begin{array}{l}\text { Nagane M. } \\
\text { [37] }\end{array}$ & $\begin{array}{l}\text { Papillary } \\
\text { Adenocarcinoma Of } \\
\text { Lung }\end{array}$ & $\begin{array}{l}\text { Adenocarcinoma Of } \\
\text { Rectum }\end{array}$ & Glioblastoma In Brain & & \\
\hline 35 & 1997 & $\begin{array}{l}\text { Potzsch } \\
\text { C.[38] }\end{array}$ & Breast Carcinoma & $\begin{array}{l}\text { Small Cell Lung } \\
\text { Carcinoma }\end{array}$ & Renal Cell Carcinoma & $\begin{array}{l}\text { Acute Myelomonocytic } \\
\text { Leukemia }\end{array}$ & \\
\hline 36 & 1997 & Shan L.[39] & $\begin{array}{l}\text { I4 Foci Of Primary SCC, } \\
\text { Esophagus, Oral Floor, } \\
\text { Soft Palate, Uvula, } \\
\text { Lingual Radix, Piriform } \\
\text { Recess, Hypopharynx, } \\
\text { Trachea, Lingual Body }\end{array}$ & & & & \\
\hline 37 & 1999 & $\begin{array}{l}\text { Cribier B. } \\
{[40]}\end{array}$ & Eccrine Porocarcinoma & Tricholemmal Carcinoma & $\begin{array}{l}\text { Multiple Squamous Cell } \\
\text { Carcinomas }\end{array}$ & & \\
\hline 38 & 1999 & $\begin{array}{l}\text { Ramsay } \\
\text { H.M.[4I] }\end{array}$ & Acute Myeloid Leukemia & $\begin{array}{l}\text { Chronic Lymphocytic } \\
\text { Leukemia }\end{array}$ & Basal Cell Carcinomas & & \\
\hline 39 & 1999 & $\begin{array}{l}\text { Schon } \\
\text { M.P.[42] }\end{array}$ & Basal Cell Carcinomas & Hairy Cell Leukemia & Basal Cell Carcinomas & & \\
\hline 40 & 2000 & $\begin{array}{l}\text { Beswick } \\
\text { S.J.[43] }\end{array}$ & Basal Cell Carcinomas & $\begin{array}{l}\text { Malignant Melanoma In } \\
\text { Situ }\end{array}$ & Basal Cell Carcinomas & & \\
\hline 41 & 2001 & Mukai [44] & Stomach Carcinoma & Duodenal Carcinoma & Esophageal Cancer & Renal Cancer & Colon Carcinoma In Situ \\
\hline 42 & 2003 & Satoh H.[5] & Carcinoma Of Kidney & $\begin{array}{l}\text { Transitional Cell } \\
\text { Carcinoma Of Bladder }\end{array}$ & Prostate Carcinoma & & \\
\hline
\end{tabular}

performed. In September of the same year, due to progressively worsening dyspnea a computed tomography was performed that revealed a mediastinal mass in conjunction to the right lung hilum and to the right main bronchus with maximum diameter of $9 \mathrm{~cm}$. Bronchoscopy showed a large mass which invaded the right main bronchus mucosa and extended to the carina. Histology of the bronchial mucosal sample showed infiltration of lamina propria by malignant cells (Figure 3A). Their immunophenotype was: CD56 (+) (Figure 3B), Pan-Cytokeratin (paranuclear dot stain positivity) (Figure 3C) and Leukocyte Common Antigen negative. Combining the morphological and the immunohistochemical results, we concluded that the patient was suffering from small cell lung carcinoma (SCLC). The patient's stage was IIIB. Ten days after the diagnosis was confirmed, the patient underwent the first cycle of chemotherapy (Cisplatin and Vepesid), during which he died from cardiac arrest due to chemotherapy toxicity.

\section{Discussion}

We report a patient who developed three histologically distinct malignancies, i.e. primary bladder carcinoma and metachronous prostate and SCLC within an eighteenmonth period. There are several predisposing or causal factors for each malignancy. For our patient there was only one common causal factor, the fact that he was a heavy smoker (90-100 packets per year). No other predisposing factor or a family history was found that might have contributed to the development of these three malignancies. The presence of bladder and prostate carcinomas in the same patient is not a rare event. Chun [3] reported that the rate of bladder carcinoma in patients with prostate carcinoma is eighteen times higher $(\mathrm{p}<0,01)$ and the rate of prostate carcinoma in those with bladder carci- noma is nineteen times higher $(\mathrm{p}<0,01)$ than expected. Although bladder and prostate carcinoma can coexist in the same individual frequently enough, the rare event is the appearance of a third malignancy. There is a case report by Rovinescu et al [4] referring to a patient with three primary malignancies. The first tumor was a clear cell carcinoma of the kidney, which was followed by a transitional cell carcinoma of the bladder and then by a distinct adenocarcinoma of the prostate. More recently, in 2003, Satoh et al [5] also reported the same combination of multiple primary malignancies in a patient. Our case is the first one of an individual having these two primary malignancies of the urogenital system and another tumor of the lower respiratory tract.

Table 1 summarizes the cases with three or more primary malignancies. As can be easily seen, although the appearance of three primary malignancies in one patient is not very common, should not be considered such a rare event.

Additionally, studying the existing bibliography, we noticed that there is a little confusion regarding the terms used, such as synchronous, simultaneous and metachronous or successive neoplasms. All of these words have to do with the time that the neoplasms are discovered and have nothing to do with the time of their genesis. The word synchronous is a Greek one that should refer to neoplasms appearing in the same time. It is synonymous to the word simultaneous and they are interchangeable. Metachronous (meta- means after and -chronous is the time) is also a Greek word referring to a neoplasm that is discovered while there is already a known neoplasm in the same patient. The word successive could be used equally to metachronous. 


\section{Conclusion}

Summarizing, it is important for the clinicians to keep in mind that the appearance of another tumor in a patient suffering from cancer could be either a metastasis or another malignancy and should always investigate the possibility of a metachronous (successive) or a synchronous (simultaneous) malignancy. Moreover, the combination of the three different neoplasms (bladder, prostate and SCLC) in one patient, to the best of our knowledge, has never been reported before.

\section{Competing interests}

The author(s) declare that they have no competing interests.

\section{Authors' contributions}

KAV wrote the original manuscript and performed histopathological evaluation of the lung lesion.

DKI participated in the writing of the original manuscript and prepared photomicrographs.

DG performed histopathological evaluation of the urinary bladder lesion.

GE performed histopathological evaluation of the prostate lesion.

FM performed bronchoscopy and patient's management.

SE prepared requested revisions of the manuscript.

\section{Acknowledgements}

The permission was obtained from the next of kin of patient for publication of this case report.

\section{References}

I. Billroth T: [General surgical pathology and therapy. Guidance for students and physicians. Lecture]. Khirurgiia (Mosk) 1991:136-143.

2. Munker R, Hiller E, Melnyk A, Gutjahr P: Second malignancies: clinical relevance and basic research. Int J Oncol 1996:763-776.

3. Chun TY: Coincidence of bladder and prostate cancer. J Urol 1997, 157:65-67.

4. Rovinescu I, Rousseau E: [Considerations relating to multiple primary carcinomas of the urinary tract (author's transl)]. I Urol Nephrol (Paris) 1976, 82:62I-626.

5. Satoh H, Momma T, Saito S, Hirose S: [A case of synchronous triple primary carcinomas of the kidney, bladder and prostate]. Hinyokika Kiyo 2003, 49:26I-264.

6. Crail HW: Multiple primary malignancies arising in the rectum, brain, and thyroid. US Naval Med Bull 1949, 49:I23-I 28.

7. Hamoudi AB, Ertel I, Newton WAJ, Reiner CB, Clatworthy HWJ: Multiple neoplasms in an adolescent child associated with IGA deficiency. Cancer 1974, 33: | | 34- | | 44.

8. Ohsato $\mathrm{K}$, Hashimoto $\mathrm{H}$, Itoh $\mathrm{H}$, et : Familial adenomatosis of the colon associated with brain tumor (Turcot's syndrome): report of a case and review of the literature (Japanese). STOMACH INTEST (Tokyo) 1975, 10:15 I 1-1517.

9. Kawanami K, Ohno M, Matsuura K, et : Turcot's syndrome: report of an autopsy case. STOMACH INTEST (Tokyo) 1976, II:1075-1082.
10. Itoh $\mathrm{H}$, Ohsato $\mathrm{K}$, Yao $\mathrm{T}$, lida $\mathrm{M}$, Watanabe $\mathrm{H}$ : Turcot's syndrome and its mode of inheritance. Gut 1979, 20:4I4-4I9.

II. Mullen JL, Reichman J, Rosato EF: Multiple carcinomas following therapy for Hodgkin disease. J Surg Oncol 1979, I I:75-78.

12. Pinel J, de Romanet JB, Fontanel JP: [Multiple carcinomas of the upper digestive tract. 7 tumour sites in 9 years (author's transl)]. Ann Otolaryngol Chir Cervicofac 1979, 96:619-62I.

13. Cohen C: Multiple cutaneous carcinomas and lymphomas of the skin. Arch Dermatol 1980, I | 6:687-689.

14. Friedman $\mathrm{CD}$, McCarthy JR: Multiple primary malignant neoplasms. IMJ Illinois Medical Journal 1982, 161:115-116.

15. Li FP, Little JB, Bech-Hansen NT, Paterson MC, Arlett C, Garnick MB, Mayer RJ: Acute leukemia after radiotherapy in a patient with Turcot's syndrome. Impaired colony formation in skin fibroblast cultures after irradiation. Am J Med I983, 74:343-348.

16. Haibach H, Rosenholtz MJ: Synchronous thyroid, renal, and duodenal carcinomas. Arch Pathol Lab Med 1984, 108:272-274.

17. Alessi E, Brambilla L, Luporini G, Mosca L, Bevilacqua G: Multiple sebaceous tumors and carcinomas of the colon. Torre syndrome. Cancer 1985, 55:2566-2574.

18. Kobayashi T: Diagnosis and treatment of multiple primary neoplasm-brain tumors and cancer of other organs. Saishin Igaku 1985, 40 : 1613-1620.

19. Megighian D, Zorat PL: A rarely observed case of primary multiple carcinomas of the head and neck. Arch Otorhinolaryngol 1985, 242:7-I2.

20. Staren ED, Roberts J: Multiple primary cancers of the respiratory tract: a case of synchronous carcinoma of the larynx, carcinoma of the floor of the mouth, and dual primary bronchogenic carcinomas. J Surg Oncol 1985, 29:261-263.

21. Craig DM, Triedman LJ: Four primary malignant neoplasms in a single patient. J Surg Oncol 1986, 32:8-10.

22. Ogasawara K, Ogawa A, Shingai J, Kayama T, Wada T, Namiki T, Suzuki ]: [Synchronous multiple primary malignant tumors accompanied by glioblastoma. Case report]. Neurol Med Chir (Tokyo) 1986, 26:908-912.

23. Hayashi K, Ohtsuki Y, Sonobe H, Takahashi K, Wada S, Yoshida K [An autopsy case of triple primary cancers consisting of glioblastoma multiforme of the pons, colon cancer and rectal carcinoid--a statistical analysis of cases of brain tumor combined with other primary cancers in Japan autopsy annuals]. Gan No Rinsho 1987, 33:1846-1853.

24. Kobayashi T, Takahashi T, Tanaka T, Tateishi T, Miura S: [Multiple primary neoplasm--glioblastoma combined with cancer of other organs]. No Shinkei Geka 1987, I 5:I0I I-I0I7.

25. Ohi H, Kikuchi K, Futawatari K, Kowada M: A histologically-verified triple cancer--report of a rare case involving a primary brain tumor. Gan No Rinsho Japan Journal Of Cancer Clinics 1988, 34:100I-1005.

26. Baigrie RJ: Seven different primary cancers in a single patient. A case report and review of multiple primary malignant neoplasia. Eur J Surg Oncol 199I, 17:8I-83.

27. Solan MJ: Multiple primary carcinomas as sequelae of treatment of pulmonary tuberculosis with repeated induced pneumothoraces. Case report and review of the literature. Am J Clin Oncol I99I, | 4:49-5I.

28. Melkert PW, Walboomers JM, Jiwa NM, Cuesta MA, Kenemans P, Meijer C): Multiple HPV I6-related squamous cell carcinomas of the vulva, vagina, anus, skin and cervix in a 31 -year-old woman. Eur J Obstet Gynecol Reprod Biol 1992, 46:53-56.

29. Marcos Sanchez F, Salvador Fernandez M, Juarez Ucelay F, Druet Ampuero J: [Carcinomas of the colon, kidney, and breast in the same patient. A new case of multiple primary malignant neoplasms]. An Med Interna 1992, 9:257-257.

30. Brugieres L, Gardes M, Moutou C, Chompret A, Meresse V, Martin A, Poisson N, Flamant F, Bonaiti-Pellie C, Lemerle J, Feunteun J: Screening for germ line p53 mutations in children with malignant tumors and a family history of cancer. Cancer Research 1993, 53:452-455.

31. Kikuchi T, Rempel SA, Rutz HP, de TN, Mulligan L, Cavenee WK Jothy S, Leduy L, Van Meir EG: Turcot's syndrome of glioma and polyposis occurs in the absence of germ line mutations of exons 5 to 9 of the p53 gene. Cancer Res 1993, 53:957-96I.

32. Shiseki M, Nishikawa R, Yamamoto $H$, Ochiai $A$, Sugimura $H$, Shitara N, Sameshima Y, Mizoguchi H, Sugimura T, Yokota J: Germ-line p53 
mutation is uncommon in patients with triple primary cancers. Cancer Lett 1993, 73:5 I-57.

33. Bumpers HL, Natesha RK, Barnwell SP, Hoover EL: Multiple and distinct primary cancers: a case report. J Natl Med Assoc 1994, 86:387-388.

34. Nishihara K, Tsuneyoshi M, Shimura H, Yasunami Y: Three synchronous carcinomas of the papilla of Vater, common bile duct and pancreas. Pathol Int 1994, 44:325-332.

35. Angeli-Besson C, Koeppel MC, Jacquet P, Andrac L, Sayag J: Multiple squamous-cell carcinomas of the scalp and chronic myeloid leukemia. Dermatology 1995, 191:321-322.

36. Hayashi T, Sagawa H, Kobuke K, Fujii K, Yokozaki H, Tahara E: Molecular-pathological analysis of a patient with three synchronous squamous cell carcinomas in the aerodigestive tract. Jpn J Clin Oncol I996, 26:368-373.

37. Nagane M, Shibui S, Nishikawa R, Oyama H, Nakanishi Y, Nomura K: Triple primary malignant neoplasms including a malignant brain tumor: report of two cases and review of the literature. Surg Neurol 1996, 45:219-229.

38. Potzsch C, Fetscher S, Mertelsmann R, Lubbert M: Acute myelomonocytic leukemia secondary to synchronous carcinomas of the breast and lung, and to metachronous renal cell carcinoma. J Cancer Res Clin Oncol 1997, 1 23:678-680.

39. Shan L, Nakamura Y, Nakamura M, Zhang Z, Jing X, Hara T, Yokoi T, Kakudo K: Synchronous and metachronous multicentric squamous cell carcinomas in the upper aerodigestive tract. Pathol Int 1997, 47:68-72.

40. Cribier B, Lipsker D, Grosshans E: Eccrine porocarcinoma, tricholemmal carcinoma and multiple squamous cell carcinomas in a single patient. Eur J Dermatol 1999, 9:483-486.

4I. Ramsay HM, Fryer A, Strange RC, Smith AG: Multiple basal cell carcinomas in a patient with acute myeloid leukaemia and chronic lymphocytic leukaemia. Clin Exp Dermatol 1999, 24:28I-282.

42. Schon MP, Reifenberger J, Von SS, Megahed M, Lang K, Gattermann N, Meckenstock G, Goerz G, Ruzicka T: Multiple basal cell carcinomas associated with hairy cell leukaemia. Br J Dermatol I999, 140:150-153.

43. Beswick SJ, Garrido MC, Fryer AA, Strange RC, Smith AG: Multiple basal cell carcinomas and malignant melanoma following radiotherapy for ankylosing spondylitis. Clin Exp Dermatol 2000, 25:38I-383.

44. Mukai M, Macuuchi H, Mukohyama S, Oida Y, Himeno S, Nishi T, Nakazaki H, Satoh S: Quintiple carcinomas with metachronous triple cancer of the esophagus, kidney, and colonic conduit following synchronous double cancer of the stomach and duodenum. Oncol Rep 200I, 8: III-II4.

\section{Publish with Bio Med Central and every scientist can read your work free of charge}

"BioMed Central will be the most significant development for disseminating the results of biomedical research in our lifetime. "

Sir Paul Nurse, Cancer Research UK

Your research papers will be:

- available free of charge to the entire biomedical community

- peer reviewed and published immediately upon acceptance

- cited in PubMed and archived on PubMed Central

- yours - you keep the copyright

Submit your manuscript here:

http://www.biomedcentral.com/info/publishing_adv.asp
BiolMedcentral 